\title{
Geoelectrical Resistivity and Hydrogeochemical Contrast between the Area that Has Been Applied with Fertilization for Long Duration and Non-Fertilization
}

\author{
Nur Islami \\ Jurusan Fisika-PMIPA, FKIP, University of Riau, Pekanbaru, Indonesia \\ Email: nris74@yahoo.com
}

\begin{abstract}
Integrated geoelectrical resistivity, hydrogeochemical and soil properties analysis methods were used to study the area that has been applied with fertilization for long duration and non-Fertilization in Machang, North Kelantan. The Machang plain is covered with Quaternary fluvial sediments overlying granite bedrock. The drainage system is dendritic with the main river flowing into the South China Sea. In this study, the area was divided into two sites. Site- 1 is the non-fertilized site, and Site- 2 is the regularly-fertilized site. At shallow depth from the surface to depths of $75 \mathrm{~cm}$ a lower average geoelectrical resistivity values were obtained from the regularly fertilized site which has not been fertilized for the last ten months prior to the survey. The average resistivity values were around 0.366 times less in unfertilized sites. Residual nitrate and chloride were still present at the regularly chemically fertilized sites. At sites where no chemical fertilizer was added, the nitrate and chloride concentration were also found. These are due to the faces excretion of from the farm animals. The presence of nitrate and chloride content in pore water reduced the resistivity values. Thus despite low moisture content, the resistivity values to remain low. Normally, resistivity values are inversely proportional to moisture content for area with similar soil condition.
\end{abstract}

Keywords: geoelectrical resistivity; hydrogeochemical; nitrate.

\section{Introduction}

Around the world, the fresh groundwater resources continue to deteriorate due to accelerated application of chemical fertilizers [1]. Like other places, in the study area, chemical fertilizers [2] are rigorously used to enhance the agricultural establishment such as for palm oil plantation. The fertilization is conducted every two months using fertilizers of different chemical content. At the beginning of the year, 400 kilograms of urea with $60 \%$ nitrogen is used for a two hectare palm plantation. Two months after that, another type of fertilizer with $15 \%$ nitrogen, $30 \%$ phosphorus, and $55 \%$ potassium (NPK) is applied to further improve the production of palm. This process is repeated in the middle of the year and continues till the end of the year. In total, at least 800 kilograms of urea is used for the fertilization of palm trees in a two hectare area per year.

Received May 19 ${ }^{\text {th }}$, 2010, Revised August 20 $0^{\text {th }}$ 2010, Accepted for publication September $6^{\text {th }}, 2010$. 
Contaminant leaching especially nitrate from agricultural soils has been widely studied [3-4]. In this study attention has been focused mainly on geoelectrical and chemical contrast investigation between the area that has been applied with fertilization for long duration and non-Fertilization. The study need to be done using the geoelectrical resistivity method to detect chemical especially nitrate contamination in groundwater. Clay soils are usually not considered to have actual high nitrate leaching potential [3].

\subsection{Geology of the Study Area}

The study area is located about $45 \mathrm{~km}$ from the beach line. Kelantan River and the high hill can be found in the west and east side, respectively. The hill is a part of the Boundary Range Composite Batholith. It consists of two major components, the Machang Batholith which is about $100 \times 20 \mathrm{~km}$, with the smaller Kerai Batholith situated on is western flank [5]. Around the hill, a lot of granite exposed can be found especially at Sungai Buluh Quarry. Other exposed granite can also be found in Kampong Pulai Condong about $4 \mathrm{~km}$ to the west of Machang Batholith Boundary Range. The study area is covered with Quaternary sediments overlying granite bedrock. It is drained mainly by short rivers and streams which flow into the South China Sea. The thickness of the Quaternary deposits varies from $20 \mathrm{~m}$ inland to about $200 \mathrm{~m}$ near the coast. The loose quaternary sediments consist of alternating layers of coarse gravels to silts or mixtures of the two [6]. Figure 1 shows the location map of the research area.

\section{$2 \quad$ Methodology}

The study was performed at Kampong Tok Bok. In this investigation, the area was divided into two sites: Site 1 is the non-fertilized land, and Site 2 is the regularly-fertilized land. Site 1 is grassy fields which are sometimes used by the local people for celebration grounds and by their farm animals for grazing. Site 2 generally consists of the old palm oil plantation. The field had been farmed recurrently for over 25 years (personal conversation with a local field supervisor). The palm oil plantation has not been fertilized since August 2007, since it is due to be replanted in the near future. The fertilization scheme for the palm oil plantation for trees more than 12 years old is shown in Table 1.

For both sites, Site 1 and Site 2, the investigation methods were used, are: a 2dimensional (2D) geoelectrical resistivity imaging survey, soil properties analysis, and water chemical analysis.

The 2D geoelectrical resistivity imaging surveys were performed at both sites using the ABEM Terrameter SAS4000 resistivity meter. The Wenner arrays were used on five lines within each Site with $1 \mathrm{~m}$ of the electrode spacing. The 
total profile length is $40 \mathrm{~m}$. Processing of the data was achieved by a tomographic inversion scheme using the software RES2DINV [7-8]. The focus of investigation is to compare the geoelectrical resistivity imaging results with soil properties and the water soil chemical content.

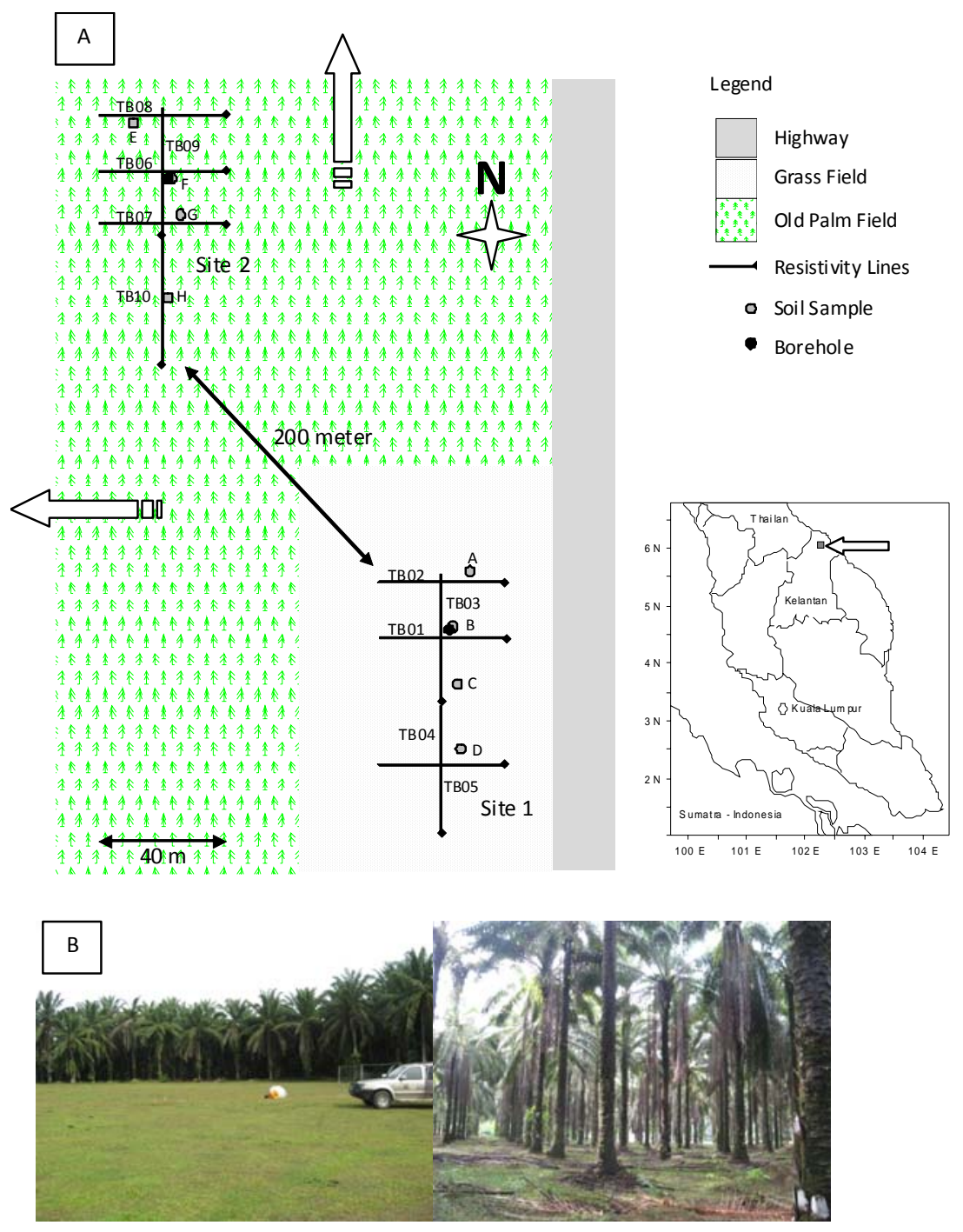

Figure 1 Map showing line surveys and soil sampling location (A). Photograph of Site investigation (B). 
Table 1 Fertilization scheme of palm oil plantation in the Site 2 Kampong Tok Bok, Area 1. The data was derived from the palm oil plantation supervisor.

\begin{tabular}{ccccc}
\hline No & Month & Fertilizer Types & Content & $\begin{array}{c}\text { Amount per 2 } \\
\text { Ha }\end{array}$ \\
\hline 1 & February & Urea & Nitrogen (60\%) & $400 \mathrm{~kg}$ \\
2 & April & NPK & N(15\%), P, K & $600 \mathrm{~kg}$ \\
3 & August & Urea & Nitrogen (60\%) & $400 \mathrm{~kg}$ \\
4 & October & NPK & N(15\%), P, K & $600 \mathrm{~kg}$ \\
5 & December & Dolomite & Dolomite & $300 \mathrm{~kg}$ \\
6 & When needed & KCl & K and Cl & $200 \mathrm{~kg}$ \\
7 & Anytime & Farmyard manure & Mixture & As available \\
\hline
\end{tabular}

Grain size distribution for both sites was measured to distinguish the different soil character [9]. Soil samples were collected randomly from four point locations at each site (see Figure 1). Each location was taken from a depth of 0 to $1 \mathrm{~m}$, at every $25 \mathrm{~cm}$ interval. The samples were then dried using an oven at $105^{\circ} \mathrm{C}$ for 24 hours. The dried soil was sieved and classified according the grain size classification scheme by Hamlin [10]. They are gravel, sand, silt and clay, respectively.

A gravimetric method [11] was adopted in measuring moisture content of four holes at each Site (Figure 1). Each hole was taken from a depth of $0 \mathrm{~m}$ to $1 \mathrm{~m}$ for $25 \mathrm{~cm}$ interval. In this methods, soil need to be weighed before drying stage. Sample and its container were heated in oven at $105^{\circ} \mathrm{C}$ for 24 hours to achieve stabilization mass at constant value (without water content). Weight reduction as gravimetrical soil moisture content was consequently estimated.

Inverse auger methods [12] were used to measure hydraulic conductivity at shallow depths above water level. A hole with an $11.5 \mathrm{~cm}$ diameter and $60 \mathrm{~cm}$ depth was made at each location. After a hole was created it was filled with water to ground surface level. The rate of decreasing water level was initially intermittent but eventually stabilized to a constant rate after some time.

To analyze the chemical content of the soil water in the vadose zone, it requires the samples to be extracted directly from the soil. Soil water was sampled at $0.25 \mathrm{~m}, 0.50 \mathrm{~m}, 0.75 \mathrm{~m}$ and $1 \mathrm{~m}$ depths for four random locations (refer to Figure 1) using a 1900 Soil Water Samplers (manufactured by Soilmoisture Equipment Corp, USA). Four soil water samples were merged into a bottle plastic of $40 \mathrm{ml}$ for each depth and labelled regarding to the depth sampling. Subsequently, the soil water samples were kept in plastic bottles and maintained 
Geoelectric al Resistivity and Hydrogeochemic al Contrast 155

at a temperature of $4^{\circ} \mathrm{C}$. The samples were analyzed in hydrgeoochemical lab using Ion Chromatography (IC) and Inductively Coupled Plasma (ICP) one day after collecting samples.

\section{$3 \quad$ Results and Discussion}

\subsection{Grain Size Distribution}

The results of the soil properties analysis (grain size and moisture content) for Site 1 and Site 2 are given in Table 2.

Table 2 Grain size distribution and moisture content of Site 1 (left) and Site 2 (right).

\begin{tabular}{|c|c|c|c|c|c|c|c|c|c|}
\hline S_ID & $\begin{array}{c}\text { Gravel } \\
\text { (\%) }\end{array}$ & $\begin{array}{l}\text { Sand } \\
(\%)\end{array}$ & $\begin{array}{c}\text { Silt } \\
\& \\
\text { Clay } \\
(\%)\end{array}$ & $\begin{array}{c}\text { (Moisture) } \\
\text { (\%) }\end{array}$ & S_ID & $\begin{array}{c}\text { Gravel } \\
\text { (\%) }\end{array}$ & $\begin{array}{l}\text { Sand } \\
\text { (\%) }\end{array}$ & $\begin{array}{c}\text { Silt \& } \\
\text { Clay } \\
(\%)\end{array}$ & $\begin{array}{c}\text { (Moisture) } \\
\text { (\%) }\end{array}$ \\
\hline A- 0 & 0.76 & 98.29 & 0.95 & 16.53 & E-0 & 0.91 & 98.15 & 0.94 & 15.76 \\
\hline A-25 & 0.00 & 98.48 & 1.52 & 11.54 & E-25 & 0.00 & 98.44 & 1.56 & 10.87 \\
\hline A-50 & 0.47 & 99.14 & 0.86 & 9.75 & E-50 & 0.00 & 99.15 & 0.85 & 9.23 \\
\hline A-75 & 1.53 & 97.81 & 0.66 & 10.33 & E-75 & 1.22 & 98.04 & 0.74 & 10.15 \\
\hline A-100 & 7.05 & 92.64 & 0.32 & 10.31 & E-100 & 6.56 & 93.10 & 0.34 & 10.37 \\
\hline Average & 1.96 & 97.27 & 0.86 & 11.69 & Average & 1.74 & 97.38 & 0.88 & 11.28 \\
\hline B-0 & 0.86 & 98.14 & 1.00 & 15.98 & F-0 & 0.85 & 98.20 & 0.95 & 15.93 \\
\hline B-25 & 0.00 & 98.44 & 1.56 & 10.44 & F-25 & 0.00 & 98.45 & 1.55 & 10.92 \\
\hline B-50 & 0.00 & 99.08 & 0.92 & 9.97 & F-50 & 0.00 & 99.12 & 0.88 & 9.72 \\
\hline B-75 & 1.44 & 97.83 & 0.74 & 11.79 & F-75 & 1.54 & 97.73 & 0.73 & 10.17 \\
\hline B-100 & 7.22 & 92.43 & 0.34 & 9.24 & F-100 & 7.23 & 92.43 & 0.34 & 10.03 \\
\hline Average & 1.91 & 97.18 & 0.91 & 11.48 & Average & 1.92 & 97.19 & 0.89 & 11.35 \\
\hline $\mathrm{C}-0$ & 0.82 & 98.21 & 0.97 & 16.29 & G-0 & 0.85 & 98.20 & 0.96 & 15.78 \\
\hline C-25 & 0.00 & 98.41 & 1.59 & 11.23 & G-25 & 0.00 & 98.45 & 1.55 & 10.79 \\
\hline C-50 & 0.59 & 99.12 & 0.88 & 10.01 & G-50 & 0.00 & 99.09 & 0.91 & 9.65 \\
\hline C-75 & 1.55 & 97.78 & 0.67 & 10.51 & G-75 & 1.56 & 97.71 & 0.73 & 10.12 \\
\hline C-100 & 7.24 & 92.40 & 0.36 & 10.23 & G-100 & 7.86 & 91.77 & 0.37 & 10.09 \\
\hline Average & 2.04 & 97.19 & 0.89 & 11.65 & Average & 2.05 & 97.04 & 0.90 & 11.29 \\
\hline D-0 & 0.81 & 98.21 & 0.97 & 16.16 & $\mathrm{H}-0$ & 0.85 & 98.20 & 0.95 & 15.69 \\
\hline D-25 & 0.00 & 98.40 & 1.60 & 11.08 & H-25 & 0.00 & 98.47 & 1.53 & 10.48 \\
\hline D-50 & 0.00 & 99.14 & 0.86 & 9.86 & $\mathrm{H}-50$ & 0.00 & 99.14 & 0.86 & 9.53 \\
\hline D-75 & 1.54 & 97.79 & 0.66 & 10.52 & H-75 & 1.52 & 97.76 & 0.72 & 10.15 \\
\hline D-100 & 7.27 & 92.39 & 0.34 & 10.18 & H-100 & 7.77 & 91.88 & 0.34 & 10.06 \\
\hline Average & 1.93 & 97.19 & 0.89 & 11.56 & Average & 2.03 & 97.09 & 0.88 & 11.18 \\
\hline
\end{tabular}


The total percentage of sand at all sampling locations ranges from $91.77 \%$ to $99.15 \%$. Maximum percentage values of sand-sized grain are observed in samples from $50 \mathrm{~cm}$ sampling levels for all location (Site 1 and Site 2). The percentage of gravel-sized grains show a distribution pattern which the percentage values increase in samples with depth.

All sampling depths of Site 1 and Site 2 show a low percentage value for silt and clay content ranging from 0.32 to $1.60 \%$. Average silt and clay content for the whole of Site 1 and Site 2 is found to be less than $1 \%$. However, with increasing depth, silt and clay content percentage notably generally decreases except at the surface level.

Generally, there is not big difference at both site (Site 1 and Site 2) regarding grain-size distribution. It can be concluded that both Site 1 and Site 2 have the same soil and geologic conditions.

Table 3 Water extraction analysis result of Site 1 (top half) and Site 2 (bottom half).

\begin{tabular}{|c|c|c|c|c|c|c|c|c|c|c|c|}
\hline No & $\begin{array}{c}\text { Sample } \\
\text { ID }\end{array}$ & $\begin{array}{c}\text { Chloride } \\
\text { mg/l }\end{array}$ & $\begin{array}{c}\text { Nitrate } \\
\text { mg/l }\end{array}$ & $\begin{array}{c}\text { Sulphate } \\
\text { mg/l }\end{array}$ & $\begin{array}{c}\text { Fluoride } \\
\text { mg/l }\end{array}$ & $\begin{array}{c}\mathrm{K} \\
\mathrm{mg} / \mathrm{l}\end{array}$ & $\begin{array}{c}\mathrm{Ca} \\
\mathrm{mg} / \mathrm{l}\end{array}$ & $\begin{array}{l}\text { Mg } \\
\text { mg/l }\end{array}$ & $\begin{array}{c}\mathrm{Na} \\
\mathrm{mg} / \mathrm{l}\end{array}$ & $\begin{array}{c}\text { Al } \\
\text { mg/l }\end{array}$ & $\begin{array}{c}\text { Fe } \\
\text { mg/l }\end{array}$ \\
\hline 1 & $\begin{array}{c}\text { TB001- } \\
25\end{array}$ & 10.262 & 2.752 & 0.491 & 0.152 & 1.953 & 2.973 & 0.571 & 4.956 & 0.196 & 0.037 \\
\hline 2 & $\begin{array}{c}\text { TB001- } \\
50\end{array}$ & 8.576 & 2.451 & 3.358 & 0.137 & 1.231 & 2.567 & 0.713 & 4.030 & 0.097 & 0.032 \\
\hline 3 & $\begin{array}{c}\text { TB001- } \\
75\end{array}$ & 7.775 & 2.579 & 5.008 & 0.373 & 1.558 & 2.188 & 0.538 & 3.920 & 0.068 & 0.012 \\
\hline \multirow[t]{2}{*}{4} & $\begin{array}{c}\text { TB001- } \\
100\end{array}$ & 5.935 & 1.357 & 0.000 & 0.155 & 1.020 & 1.279 & 0.395 & 2.794 & 0.043 & 0.008 \\
\hline & Average & 8.137 & 2.285 & 2.214 & 0.204 & 1.441 & 2.252 & 0.554 & 3.925 & 0.101 & 0.022 \\
\hline 1 & $\begin{array}{c}\text { TB006- } \\
25\end{array}$ & 20.502 & 9.116 & 0.000 & 0.432 & 2.545 & 3.957 & 0.288 & 4.340 & 0.600 & 0.274 \\
\hline 2 & $\begin{array}{c}\text { TB006- } \\
50\end{array}$ & 13.103 & 6.777 & 3.031 & 0.398 & 2.479 & 3.941 & 0.333 & 4.611 & 0.406 & 0.056 \\
\hline 3 & $\begin{array}{c}\text { TB006- } \\
75\end{array}$ & 10.259 & 6.104 & 0.000 & 0.523 & 1.929 & 3.139 & 0.264 & 6.769 & 0.741 & 0.087 \\
\hline \multirow[t]{2}{*}{4} & $\begin{array}{c}\text { TB006- } \\
100\end{array}$ & 9.819 & 5.136 & 1.644 & 0.044 & 1.162 & 1.439 & 0.150 & 2.207 & 0.083 & 0.011 \\
\hline & Average & 13.421 & 6.783 & 1.169 & 0.349 & 2.029 & 3.119 & 0.259 & 4.488 & 0.458 & 0.107 \\
\hline
\end{tabular}

\subsection{Moisture Content}

At Site 1, average moisture content ranges from $11.48 \%$ to $11.69 \%$ (Table 2). A highest percentage value for moisture content is at location A. At each location, maximum values of moisture content are obtained at the surface. Though moisture content increases slightly in the near subsurface for location A. The moisture content does not show similar trend. 
The two Sites differ in average moisture content percentages with Site 1 has an average of $11.59 \%$ with $0.09 \%$ standard deviation and Site 2 average of $11.27 \%$ with $0.07 \%$ standard deviation, respectively. Differences in moisture content is attributed to the different rate evaporate. Data for Site 1 was acquired one day prior to data for Site 2. Even though, it the weather conditions of the two days of data acquisition were nearly the same (cloudy), thus resulting in the not big difference percentage values for moisture content for both sites.

\subsection{Hydraulic Conductivity}

For both Site 1 and Site 2, the hydraulic conductivity was recorded to be $0.001079 \mathrm{~cm} / \mathrm{s}$ and $0.001096 \mathrm{~cm} / \mathrm{s}$ respectively (Figure 2 and Table 4). The value informs that the pore soil characters for both Sites, which it imply to the similarity of their porosity and permeability for both Sites.
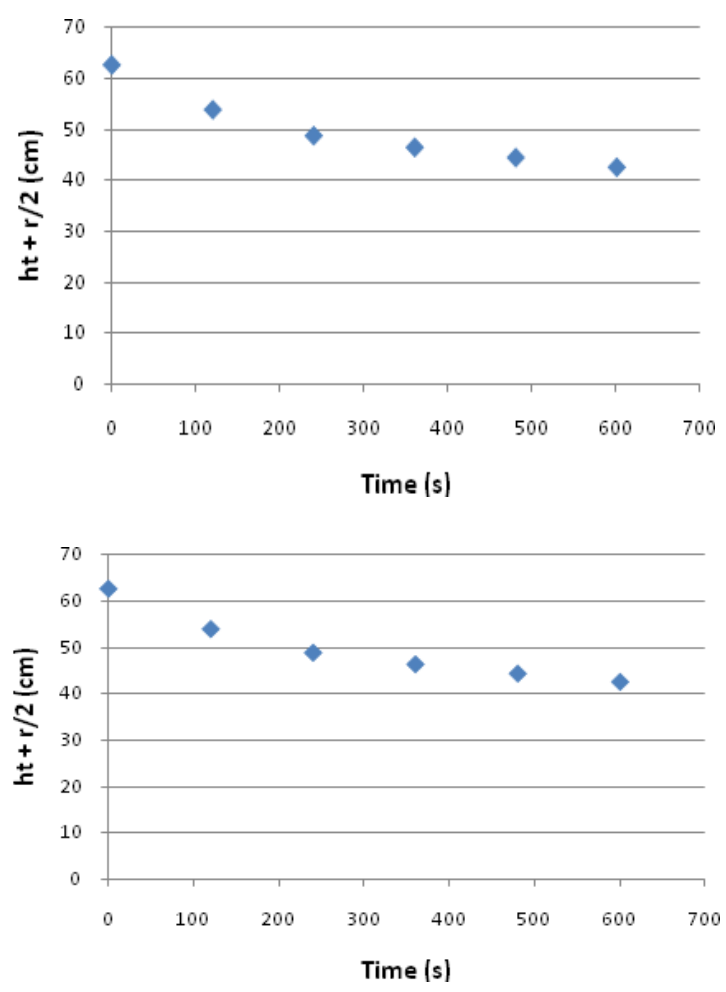

Figure 2 Result of “k” test for Site 1 (A) and Site 2 (B). 
Table 4 Statistical values of resistivity extraction derived from surface to 75 $\mathrm{cm}$ depth. At the right side, soil properties value within the Site 1 and Site 2 exhibits their mean and standard deviation (in bracket) derived from surface to $75 \mathrm{~cm}$ depth

\begin{tabular}{|c|c|c|c|c|c|c|c|c|c|c|}
\hline & \multicolumn{5}{|c|}{ Inverse resistivity model values (ohm.m) } & \multicolumn{5}{|c|}{ Soil properties values } \\
\hline & $\begin{array}{c}\text { Line } \\
\text { Name }\end{array}$ & $\begin{array}{l}\text { Mean } \\
\text { resist }\end{array}$ & Stdev & Max & Min & $\begin{array}{c}\text { Gravel } \\
(\%)\end{array}$ & $\begin{array}{l}\text { Sand } \\
(\%)\end{array}$ & $\begin{array}{c}\text { Silt \& } \\
\text { Clay } \\
(\%)\end{array}$ & $\begin{array}{c}\text { Moisture } \\
\text { (\%) }\end{array}$ & $\begin{array}{c}\mathrm{K} \\
(\mathrm{cm} / \mathrm{s})\end{array}$ \\
\hline \multirow{5}{*}{$\begin{array}{c}\text { Site } \\
1\end{array}$} & TB001 & 4042.62 & 1245.367 & 8021 & 2084.3 & \multirow{5}{*}{$\begin{array}{c}1.95 \\
(2.74)\end{array}$} & \multirow{5}{*}{$\begin{array}{l}97.20 \\
(2.47)\end{array}$} & \multirow{5}{*}{$\begin{array}{c}0.88 \\
(0.41)\end{array}$} & \multirow{5}{*}{$\begin{array}{c}11.5975 \\
(2.45)\end{array}$} & \multirow{5}{*}{0.001079} \\
\hline & ТВ002 & 4950.52 & 1275.909 & 8496.8 & 2873.5 & & & & & \\
\hline & TB003 & 4303.951 & 1358.411 & 9065 & 1932.4 & & & & & \\
\hline & TB004 & 3995.408 & 1201.233 & 6783.1 & 1466 & & & & & \\
\hline & ТВ005 & 4003.477 & 1328.22 & 8940.9 & 1980.5 & & & & & \\
\hline \multirow{5}{*}{$\begin{array}{c}\text { Site } \\
2\end{array}$} & ТВ006 & 2597.096 & 1300.075 & 7825.7 & 290.5 & \multirow{5}{*}{$\begin{array}{c}1.93 \\
(2.84)\end{array}$} & \multirow{5}{*}{$\begin{array}{l}97.17 \\
(2.55)\end{array}$} & \multirow{5}{*}{$\begin{array}{c}0.89 \\
(0.39)\end{array}$} & \multirow{5}{*}{$\begin{array}{c}11.2745 \\
(2.35)\end{array}$} & \multirow{5}{*}{0.001096} \\
\hline & ТВ007 & 2270.121 & 1127.833 & 6605 & 944.42 & & & & & \\
\hline & ТВ008 & 2718.001 & 1326.222 & 7173 & 933.97 & & & & & \\
\hline & ТВ009 & 2872.892 & 719.566 & 4636.3 & 885.07 & & & & & \\
\hline & ТВ010 & 3027.621 & 936.733 & 5881.7 & 1375.9 & & & & & \\
\hline
\end{tabular}

\subsection{Water Chemical Result}

The chemical composition of extracted water from each depth sampling at Site 1 and Site 2 is given in Table 3. In both Sites, Site 1 and Site 2, K, Ca, and Na are dominant anions with values ranging from 1.02 to $6.79 \mathrm{mg} / \mathrm{l}$. The other anions have low concentration of less than $1 \mathrm{mg} / \mathrm{l}$. Based on the results, anion content in the extracted water is similar for both sites.

In the Site 1 and Site 2, nitrate concentration ranges from 1.3 to $2.7 \mathrm{mg} / \mathrm{l}$ and 5.1 to $9.1 \mathrm{mg} / \mathrm{l}$ respectively. Highest nitrate concentration for both sites is found at the surface level and decreased with depth. In this case, after ten month fertilization, nitrate concentration in water soil can be used for human composition. USEPA [13] recommended that nitrate concentration in the water safe for human consumption is not more than $10 \mathrm{mg} / \mathrm{l}$. The same trend is also recognized for chloride concentration. Meanwhile, sulphate and fluoride has concentration value ranging from 0 to $5 \mathrm{mg} / \mathrm{l}$ and 0.1 to $0.5 \mathrm{mg} / \mathrm{l}$ respectively. However, relatively higher average concentration of chloride and nitrate cations was observed from Site 2 (Figure 3). 
Geoelectric al Resistivity and Hydrogeochemical Contrast 159

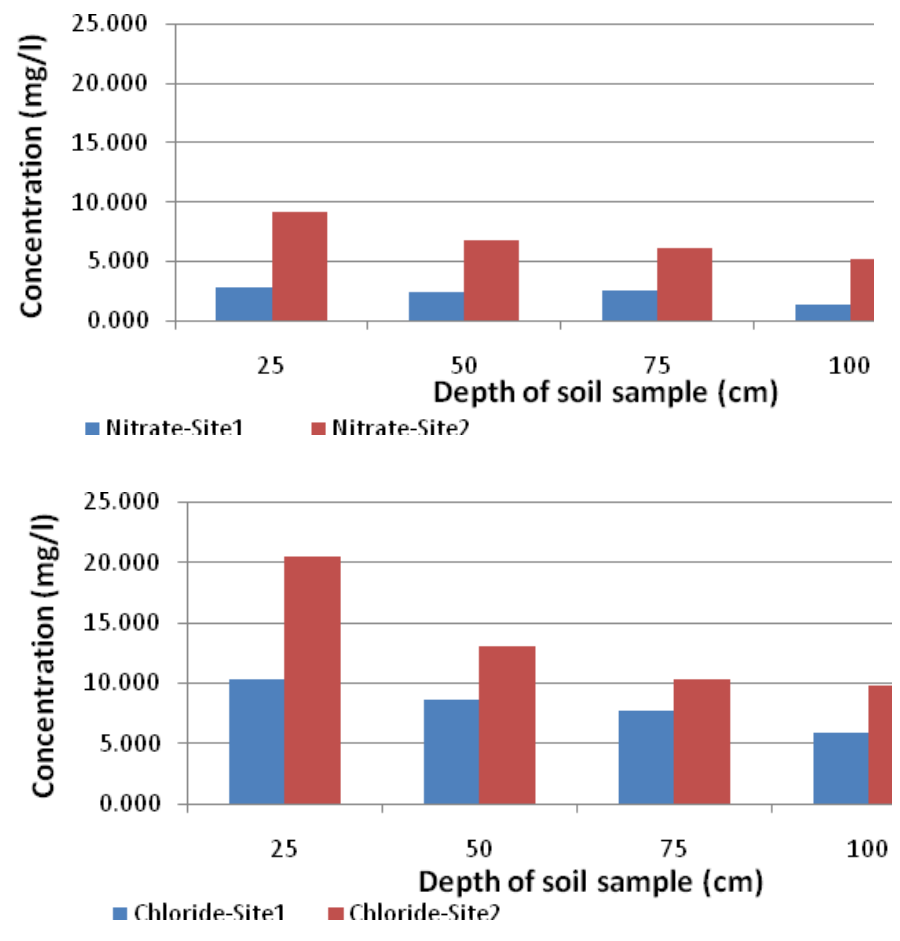

Figure 3 Nitrate (A) and chloride (B) concentration in Site1 and Site2.

\subsection{Resistivity Model}

The resistivity model of Site 1 is shown in Figure 4 . The same scale is used for all sections. In section TB01, a high-resistivity value ranging between 2000$6000 \mathrm{ohm}$.m was obtained from the surface level to a depth of around $1.5 \mathrm{~m}$, corresponding to the presence of compact sand with low moisture content (Table 3). The same feature is also observed in other sections (TB02-TB05).

The measured water table was $3.60 \mathrm{~m}$ below the ground surface in the borehole that was drilled at the $19 \mathrm{~m}$ mark of line TB003. In the inverse model of the line TB003, resistivity values of approximately $500 \mathrm{ohm}$.m corresponded to a unit of compact sand with fully saturated. 


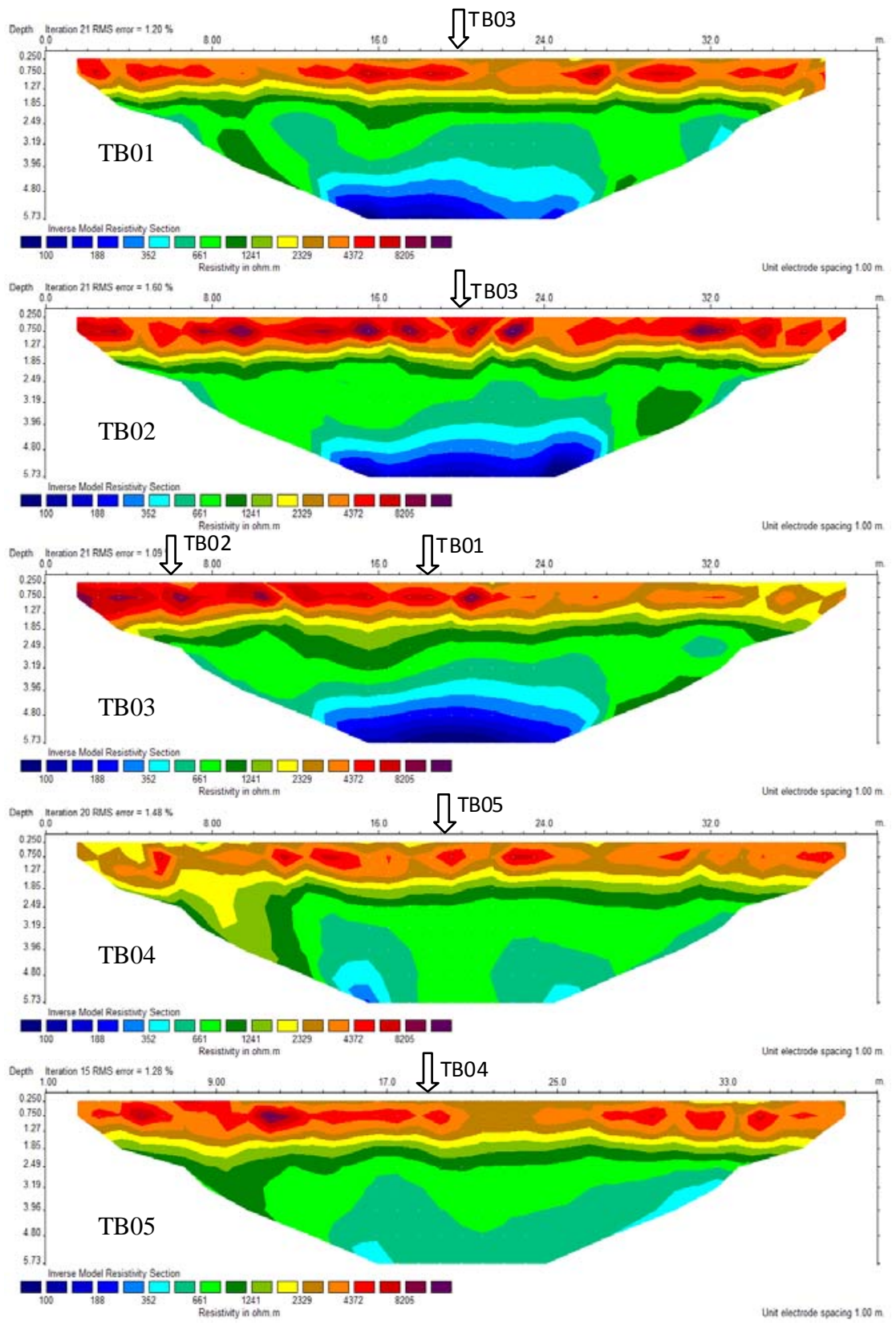

Figure 4 Wenner resistivity inverse model of Site 1. 


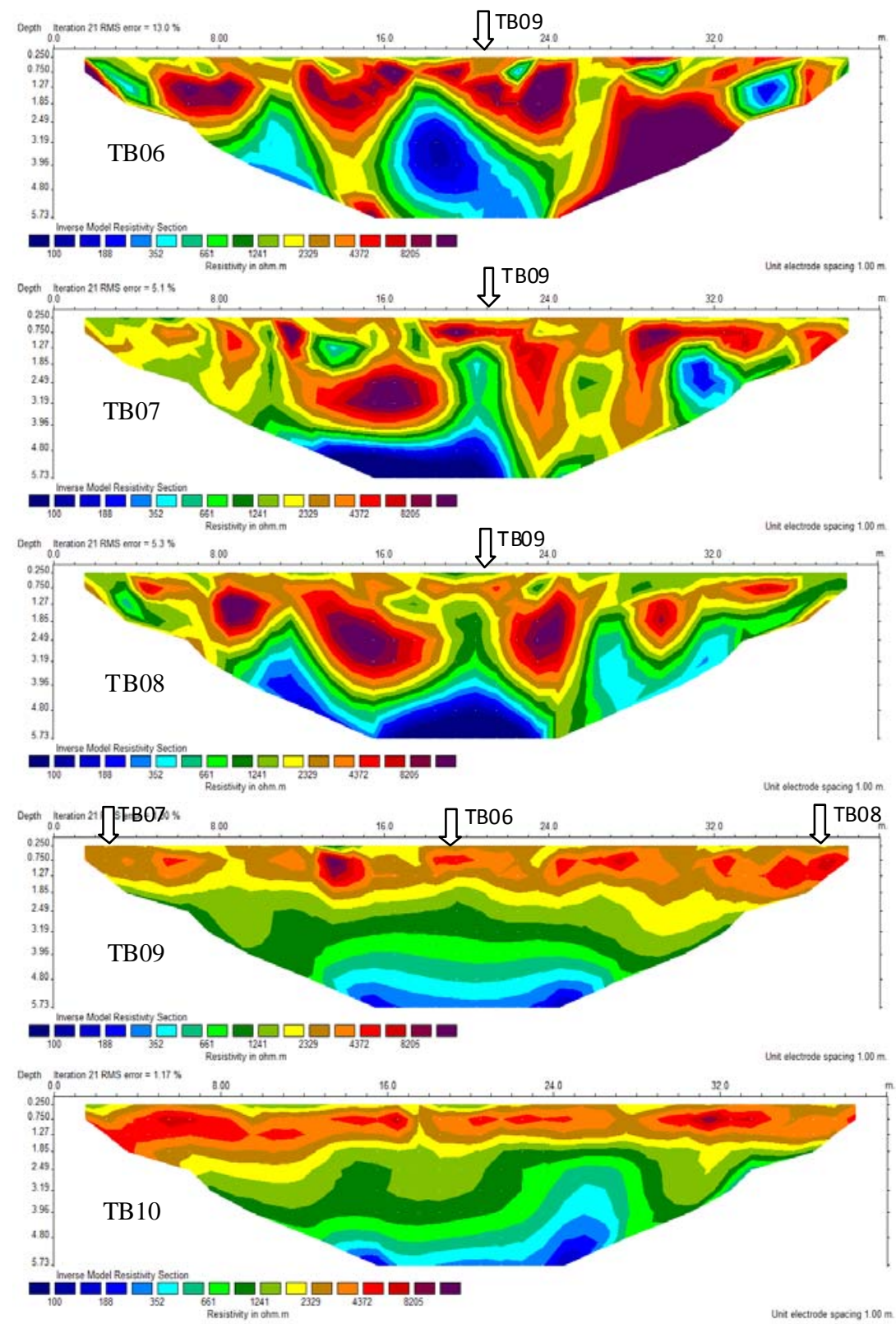

Figure 5 Wenner resistivity inverse model of Site 2. 
Generally, at a depth of more than $4 \mathrm{~m}$, zones that are probably more porous and more permeable can be seen in the section with values of around 150 ohm.m. This value corresponds to the fully saturated zone. The line TB03 crosses with the lines TB01 and TB02, and TB04 crosses with TB05 (refer to Figure 1). The intersection point is marked with an arrow in Figure 4. The results show consistency good correlation with the zones for every of line crossing, leading to reliable subsurface interpretation.

Site 2 is located northwest of Site 1 in an old palm oil plantation. The geoelectrical surveys were conducted for five lines in this site. In the inverse model of all lines (TB06-TB10 in Figure 5) show relatively lower resistivity values (1800 ohm.m) from the surface up to $1 \mathrm{~m}$ deep. This resistivity value (coloured yellow) does not appear in inverse model of the Site 1. Zones with fairly high resistivity values (more than $8000 \mathrm{ohm} . \mathrm{m}$ ) in sections TB06, TB07, and TB08 correspond to certain features presence of compact material with low moisture content at Site 2. These features are weathered boulders that known after being drilled with hand auger.

The line TB09 crosses with the lines TB06, TB07, and TB08 at the 16.5 m mark (refer to Figure 1). The inverse model shows quite good correlation with the zones at each of the line crossing. More porous and permeable zones exhibit resistivity values of about $150 \mathrm{ohm} . \mathrm{m}$ at depths of more or less than $3 \mathrm{~m}$ below the ground surface. The water table was found at a depth of $3.48 \mathrm{~m}$ in a borehole that was drilled using conventional augering at the $20 \mathrm{~m}$ mark along TB009 line (refer to Figure 1). In the inverse model of line TB009, resistivity values of around 500 ohm.m correspond to the fully saturated compact sand unit.

\subsection{Correlation of Soil Parameters, Chemical Content of Extracted Water, And Geophysical Parameters}

Table 4 shows the statistical summary of the extracted resistivity models for both sites (left-hand side of the table) and the standard deviations of selected soil properties (right-hand side of the table). The average gravel content at Site 1 and Site 2 is $1.96 \%$ and $1.94 \%$, respectively. Standard deviations for those readings are 2.74 and 2.84 for Site 1 and Site 2, respectively. Average sand content for Site 1 and Site 2 is $97.20 \%$ and $97.12 \%$ respectively. Average silt and clay contents are similar for both sites. The similarity of soil grain size indicates parallel geological conditions at both sites.

Soil properties data is supported by inversed auger data. The hydraulic conductivity of Site 1 and Site 2 was reported to be $0.001079 \mathrm{~cm} / \mathrm{s}$ and $0.001096 \mathrm{~cm} / \mathrm{s}$, obtained using the inversed auger method. Based on the results, 
it is concluded that the hydraulic conductivity that implied porosity and permeability for both sites in considered to be similar. To ease analysis, reverse values of the resistivity model were extracted from both sites and were plotted in Table 4. All data extracted from the resistivity model is displayed as $\mathrm{X}$ and Y. Based on the data in Table 4, the maximum average resistivity values from the surface to a $75 \mathrm{~cm}$ depth for both sites is $4950.52 \mathrm{ohm} . \mathrm{m}$ (TB002) and 3027.627 ohm.m (TB010), respectively. Other lines show the lower resistivity values at Site 2 compared to Site 1 from surface level to a depth of $75 \mathrm{~cm}$.

In Figure 4, the distribution relatively high resistivity values zone at depths less than $1 \mathrm{~m}$ is obvious. Within this depth interval, the relatively high resistivity values are constant, with inverse resistivity values at TB03 being the highest resistivity values at Site 1 . The analyses indicate the result value for the resistivity model at Site 1 is higher than those from Site 2 . The moisture content at Site 2 however is lower than Site 1. The values of soil properties reveal that the soil conditions at Site 1 and Site 2 are similar to each other. This similarity is reflected in the average percentages of clay, silt, and sand contents at both sites. Other measurements include the measurements conducted for the hydraulic conductivity. The lower average resistivity of Site 2 from the surface to a depth of $75 \mathrm{~cm}$ is believed to be caused by the higher nitrate and chloride concentrations in the near subsurface. Although fertilizing activities had been stopped for the past year, residual chloride and nitrate still remain in the soil. The negative charges of nitrate and chloride content caused a decrease of the medium's resistivity. This is the reason why there is a $36.6 \%$ decrease in average resistivity from the surface to depths of $75 \mathrm{~cm}$ for Site 2 .

\section{Conclusion}

The geoelectrical resistivity and hydrogeochemical methods were successful for studying of shallow groundwater aquifer characters within agricultural areas. In the preliminary study, it is found that area around palm oil plantation, nitrate concentration is higher compared to the area with no palm oil plantation. Application of chemical and natural fertilizer is the reason for the high nitrate concentration found in the palm oil plantation. In the zone with higher nitrate concentration, subsurface geoelectrical resistivity values are to be lower although the moisture content is lower and soil properties are similar. Subsurface resistivity value is higher in the zone with lower nitrate content although moisture content is higher.

\section{Acknowledgements}

The author would like to express his deepest gratitude and sincere thanks to his supervisors Assoc Prof.Dr. Samsudin Hj Taib and Assoc Prof.Dr. Ismail Yusoff for their support in performing this research. 


\section{References}

[1] Islami, N., Samsudin, T. \& Yusoff, I., Geoelectrical Resistivity and Hydrogeochemical Methods for Groundwater Investigation in the Agriculture Area: A Case Study from Machang - Malaysia, Full Paper (Proc.) in Int. Symp. \& The $2^{\text {nd }}$ AUN/SEED-Net Regional Conf. on GeoDisaster Mitigation in ASEAN, Bali, February, pp. 25- 26, 2010.

[2] Yang, S.M., Li, F.N., Suo, D.R. \& Guo, T.W., Effect of Long-Term Fertilization on Soil Productivity and Nitrate Accumulation in Gansu Oasis, Agricultural Sciences in China 2006, 5(1), 57-67, 2006.

[3] Almasri, M.N. \& Kaluarachchi, J.J., Assessment and management of long-term nitrate pollution of ground water in agriculture-dominated watersheds, J. of Hydrology, 295(1-4), 225-245, 10 August 2004.

[4] Saadi, Z. \& Maslouhi, A., Modeling nitrogen dynamics in unsaturated soils for evaluating nitrate contamination of the Mnasra groundwater, Advances in Environmental Research, 7, 803-823, 2003.

[5] Cobbing, E.J. \& Pitfield, P.E.J., The Granites of the South-East Asian tin belt, British Geological Survey, Overseas Memoir 10, 1992.

[6] Saim, S., Groundwater protection in North Kelantan, Malaysia, SOURCE: Seminar on Water: Forestry and Landuse Perspectives (30-31 Mar 1999: Kuala Lumpur), Paper 11 (11p.), 1999.

[7] Loke, M.H., Rapid 2-D Resistivity \& IP inversion using the least-squares method, Geoelectrical Imaging 2D \& 3D, Geotomo Software, Malaysia, www.geoelectrical.com, 2007.

[8] Loke, M.H. \& Barker R.D., Rapid least-squares inversion of apparent resistivity pseudosections using a quasi-Newton method, Geophysical Prospecting, 44, 131-152, 1996.

[9] Das, B.M., Principles of geotechnical engineering, fifth edition, California State Univ., 2001.

[10] Hamlin, W.K., Earth Dynamic Systems, $6^{\text {th }}$ Ed., Bringham Young Univ., Provo, Utah, 1991.

[11] Black, C.A., Methods of soil analysis, Part 1: Physical and mineralogical properties, The American Society of Agronomy, No. 9, Madison, Wisconsin, USA, 1965.

[12] Van Hoorn, J.W., Determining hydraulic conductivity with the inversed auger hole and infiltrometer methods. http://www.2.alterra.wur.n/webdocs/ilri-publicaties/Pub25/pub25h4.2.pdf, accessed 2007.

[13] U.S. EPA, Nitrogen-ammonia/nitrite/nitrate, water quality standards criteria summaries. GPO: 1980-341-082/107. Washington, DC, 1980. 